\title{
UNIVERSITY OF TEXAS RADIOCARBON DATES I
}

\author{
J. J. STIPP, ${ }^{*}$ E. MOTT DAVIS, JOHN E. NOAKES, ** \\ and TOM E. HOOVER
}

\author{
Radiocarbon Dating Laboratory, Balcones Research Center, \\ University of Texas, Austin, Texas
}

The $\mathrm{C}^{14}$ Dating Laboratory of the University of Texas has been working on the development of two systems of counting: gas counting with methane, and liquid scintillation counting with benzene. Lack of adequate instrumentation has retarded the work on gas counting, but the liquid scintillation work, supported in part by the Department of Chemistry, finally led to the successful development of a system in which the benzene counting solvent was synthesized from acetylene by pyrolysis (Tamers, Stipp, and Collier, 1961).

By coincidence, while the work on liquid scintillation was going on at the University of Texas, Noakes was doing work at the A. \& M. College of Texas on a low temperature catalytic method of benzene conversion for radiocarbon dating (Noakes, Isbell, and Hood, 1961; Anonymous, 1961). We eventually learned of each other's work, and it became evident that collaboration would be of mutual benefit. The better points of the two systems were combined, the catalytic method being chosen for the benzene conversion. A preparation system was built at the University of Texas laboratory, and a Packard Tri-Carb Liquid Scintillation Spectrometer was made available at the A. \& M. College of Texas and calibrated for low level $\mathrm{C}^{14}$ counting. The cooperative effort led to successful routine dating, and produced the dates reported here.

The two laboratories are still working together, but each expects soon to have a complete system, and thereafter they will operate independently. The dates published here are those which relate specifically to research at the University of Texas; A. \& M. College of Texas dates will be published separately by that laboratory.

In the liquid scintillation technique used, the chemistry up to the conversion of $\mathrm{C}_{2} \mathrm{H}_{2}$ to $\mathrm{C}_{6} \mathrm{H}_{6}$ has been described in detail elsewhere (Tamers, Stipp and Collier, 1961). Briefly, the sample is converted to $\mathrm{CO}_{2}$ and precipitated as $\mathrm{SrCO}_{3}$. The dried carbonate is mixed with $\mathrm{Mg}$ powder and converted to $\mathrm{SrC}_{2}$ by high temperature solid state reaction. Hydration of the carbide produces $\mathrm{C}_{2} \mathrm{H}_{2}$.

The technique developed by Noakes, Isbell and Hood (1961) for converting $\mathrm{C}_{2} \mathrm{H}_{2}$ to $\mathrm{C}_{6} \mathrm{H}_{6}$ is based on the catalytic method of Shapiro and Weiss (1957). Further significant improvements have been made since the initial announcement, and are to be described in a paper being prepared by Noakes and others. In brief, the $\mathrm{C}_{2} \mathrm{H}_{2}$ is passed through a column containing silicaalumina catalyst activated by diborane, and benzene is produced which is shown by gas chromatography to be pure. The yield is $50 \%$ to $60 \%$.

With the addition of phosphors the sample is ready to be counted in the scintillation counter with $52 \%$ efficiency. Samples and standards are sealed in

* Present address: Packard Instrument Company, Inc., Box 428, La Grange, Illinois.

** Present address: Marine Science, University of Alaska, College, Alaska. 
$20 \mathrm{ml}$ low-potassium glass ampoules and can thus be recounted at any time. The amount of sample benzene counted varies from $0.5 \mathrm{ml}$ to $20 \mathrm{ml}$, depending on initial sample size and its relative importance. For instance, if a sample were very old the full $20 \mathrm{ml}$ could be used, the theoretical age limit being $52,000 \mathrm{yr}$, utilizing a 2 -sigma criterion and $48 \mathrm{hr}$ counting period.

Our modern standard is obtained from known ring intervals of a tree felled in Central Texas between 1850 and 1854. Backgrounds are obtained by counting pure commercial benzene which has its origin in ancient carbon. Our modern count rate is $6.63 \mathrm{c} / \mathrm{m} / \mathrm{gm}$ carbon with a background count of 15.65 counts/min. Both are very reproducible (except for small background variations as noted below), indicating negligible non-constant isotopic fractionation and excellent counter stability. Although no mass spectrographic determination of $\mathrm{C}^{13} / \mathrm{C}^{12}$ ratios has been made by our laboratories, since neither laboratory has an instrument available, indications are that a small amount of isotopic fractionation takes place in the step of converting to carbide, in which the reaction reaches only 95\% completion. By contrast, Weiss and Shapiro (1958), using deuterium-labeled acetylene, found no fractionation occurring in the conversion from acetylene to benzene. Carbon fractionation in this step would be considered less likely, since the mass difference between $\mathrm{C}^{14}$ and $\mathrm{C}^{12}$ is much less than the mass difference between $\mathrm{H}^{2}$ and $\mathrm{H}$.

Concurrently with the dating program we are carrying out further experiments with the benzene synthesis, and indications are that the efficiency of this step can be increased significantly. Also, recent observations and communications with companies engaged in liquid scintillation work point to counting efficiencies approaching $80 \%$, without raising background, through the use of a new phosphor and modified counting vials.

A small difference has been noted between backgrounds of different counting vials, which will affect the statistics quoted by an undetermined but small amount. We are working on the elimination of this factor, with the cooperation of the Packard Instrument Company.

The statistics quoted here indicate only the uncertainty involved in counting random events. Ages are calculated on a half-life of $5568 \mathrm{yr}$, using A.D. 1950 as the reference yr.

\section{ACKNOWLEDGMENTS}

Dr. Donald Hood of the Department of Oceanography and Meteorology at the A. \& M. College of Texas made available the use of two counting instruments. Dr. Ruble Langston of the Department of Plant Physiology at the same institution also generously made available his liquid scintillation counter for rechecking several samples.

The $\mathrm{C}^{14}$ dating laboratories of the U. S. Geological Survey, the University of Pennsylvania, and the Shell Development Company have provided us with a number of check samples. Those used in the course of our work on liquid scintillation are from the Geological Survey, and we are indebted to Dr. Meyer Rubin for supplying them.

Grateful acknowledgment is made to the collectors and donors of the samples for assistance in compiling field information and comments; to $\mathrm{F}$. 
Howard Hughes, William R. Jackson, Jr., Donald J. Foxall, Kenneth A. Bennett, and Jules R. Gipson for technical assistance in the laboratory; and to the Departments of Anthropology, Geology, Chemistry, and Physics, the Texas Archeological Salvage Project, the Vertebrate Paleontology Laboratory, and the Balcones Research Center, all of the University of Texas, for continued support and cooperation.

\section{SAMPLE DESCRIPTIONS}

\section{CHECK SAMples (GEOlogic)}

\section{Tx-1. Grand Forks, North Dakota}

$10,820 \pm 190$

Wood from sand overlying till of the last ice advance in North Dakota; from $15 \mathrm{mi}$ W of Grand Forks, in NW1/4 sec. 31, T $152 \mathrm{~N}, \mathrm{R} 52 \mathrm{~W}\left(47^{\circ} 56^{\prime}\right.$ N Lat, $97^{\circ} 22^{\prime}$ W Long), Grand Forks County, North Dakota. Coll. 1958 by R. W. Lemke, U. S. Geol. Survey, Denver, Colorado, and H. E. Wright, Jr., Univ. of Minnesota, Minneapolis, Minnesota; subm. to Univ. of Texas lab. in 1961 as a check sample by Meyer Rubin, U. S. Geol. Survey, Washington, D. C. Comment: sample has also been dated by U. S. Geol. Survey as W-723, $10,690 \pm 300$ (USGS V).

\section{Tx-2. Sheep Creek, Alaska}

$5925 \pm 275$

Wood from stump in $\mathrm{W}$ wall of placer cut, Sheep Creek, near Fairbanks, in $\mathrm{SE} 1 / 4$ sec. $17, \mathrm{~T} 1 \mathrm{~N}, \mathrm{R} 2 \mathrm{~W}\left(64^{\circ} 55^{\prime} \mathrm{N}\right.$ Lat, $148^{\circ} 00^{\prime} \mathrm{W}$ Long), Fairbanks D-2 Quadrangle, Alaska. From ca. $5 \mathrm{ft}$ below surface of a gravel fan interbedded in silt representing perhaps the last third of the Quaternary Period. The gravel overlies the Wisconsin-age Goldstream muck formation, or is part of the upper part of it, and is perennially frozen. Coll. 1956 by T. L. Péwé, L. S. Geol. Survey, College, Alaska; subm. 1961 to Univ. of Texas Lab. as a check sample by Meyer Rubin, U. S. Geol. Survey, Washington, D. C. Comment: sample has also been dated by U. S. Geol. Survey as W-859, 5940 土 250 (USGS V).

\section{Tx-3. Hutchins Creek, Illinois}

$5535 \pm 175$

Wood from terrace segment on Hutchins Creek, in NW1/4 SW1/4 SW1/4 sec. 25, T $11 \mathrm{~S}, \mathrm{R} 3 \mathrm{~W}\left(37^{\circ} 32^{\prime} \mathrm{N}\right.$ Lat, $89^{\circ} 23^{\prime} \mathrm{W}$ Long), Union County, Illinois. Taken from log at 24 - $\mathrm{ft}$ depth below the terrace surface in silt containing layers of well-preserved leaves as well as two large logs. Coll. 1957 by S. E. Harris, Jr., Southern Illinois Univ., Carbondale, Illinois; subm. 1961 to Univ. of Texas lab. as check sample by Meyer Rubin, U. S. Geol. Survey, Washington, D. C. Comment: sample has also been dated by U. S. Geol. Survey as W-823, $4840 \pm 300$ (USGS V).

\section{ARCHAEOLOGIC SAMPLES}

\section{A. Oklahoma}

\section{Tx-4. Spiro site, Oklahoma}

$1144 \pm 165$

Wood from timber removed from central tomb in Craig Mound, Spiro site $\left(35^{\circ} 15^{\prime} \mathrm{N}\right.$ Lat, $94^{\circ} 20^{\prime} \mathrm{W}$ Long), N of Spiro, Le Flore County, Oklahoma. 
Coll. about 1935 by F. E. Clements, Univ. of Oklahoma; subm. 1954 by R. E. Bell, Univ. of Oklahoma, Norman, Oklahoma. Comment: sample is from the same lot of beams, but not necessarily from the same tree, as those dated earlier from this tomb: M-14, 2286 \pm 200 , and M-54, $640 \pm 250$ (Michigan I) ; and 0-596, $500 \pm 100$ (Bell, 1958). Other samples from the Spiro site are M-309, $480 \pm 200$ (Michigan IV), and M-816, $1170 \pm 150$ (Michigan V). Spiro Focus dates from other sites are: Reed site, M-819, $1100 \pm 150$ (Michigan V) ; Brackett site, 0-606, $700 \pm 100$ (Bell, 1958); Norman site, M-818, $1050 \pm 150$ (Michigan V), and 0-595, $1000 \pm 100$ (Bell, 1958); Hughes site, M-817, $1050 \pm 150$ (Michigan V), and 0-594, $875 \pm 100$ (Bell, 1958); Harlan site, M-64, $1280 \pm 300$, and M-65, $720 \pm 200$ (Michigan III). Although the dates from the Spiro site vary a good deal, the present sample and M-816 provide two dates that are quite close together, and since they are generally in agreement with dates from Reed, Norman, Hughes, and Harlan, these two dates, Tx-4 and M-816, are considered the most reasonable ones of the Spiro site series.

\section{B. Central Texas}

Three major archaeologic periods are recognized in Central Texas: Paleo-American or Early Man; Archaic, represented by the Edwards Plateau Aspect; and Neo-American, represented by the Central Texas Aspect. The dating of these periods, and of possible subdivisions within them which are currently under study, has in the past been largely a matter of conjecture based on parallels with other areas where dating studies are further advanced. The dates reported below constitute the first systematic series for the area (the few dates announced previously are listed in Campbell, 1961). Consequently, the comments on the dates are necessarily preliminary, and it will be noted that there is some variation of opinion as to what dates are appropriate for certain times in the archaeologic sequence. It would be premature to try to reconcile these differences at this point.

\section{Kincaid Shelter series, Texas}

Charcoal and shell samples from the Kincaid Shelter (41 UV 2), at the edge of the Sabinal River valley, $3 \mathrm{mi} \mathrm{N}$ of Sabinal, Uvalde County, Texas $\left(29^{\circ} 22^{\prime} \mathrm{N} \mathrm{Lat}, 99^{\circ} 28^{\prime} \mathrm{W}\right.$ Long). Six stratigraphic zones were distinguishable in the site, of which the top three-Zones 4,5 , and 6-contained evidences of human occupation. Zone 4 contained late Pleistocene fossil animal remains and non-distinctive artifacts. Zones 5 and 6 were part of the fill of an alluvial terrace $(25 \mathrm{ft}$ above the present Sabinal River channel) which extended into the shelter. Zone 5, the major zone in the site, contained artifacts of the Edwards Plateau Aspect. Zone 6 contained both Edwards Plateau and Central Texas Aspect artifacts, with a few historic (European) materials at the top. One $\mathrm{C}^{14}$ date has been determined for Zone 6: C-698, $1212 \pm 300$ (Chicago III). The significance of this date is problematical, since the zone appears to be mixed.

The site was excavated by the Texas Memorial Mus. in 1948, and by a field school of the Dept. of Anthropology, Univ. of Texas in 1953. Samples reported here were coll. by the latter group and subm. in 1953 by T. N. Campbell, 
Dept. of Anthropol., Univ. of Texas, Austin. With one exception (Tx-13), they all are from Zone 5 in the terrace-fill in front of the shelter.

Tx-5. Kincaid Nos. 9, 15, 61

$\mathbf{1 0 4 5} \pm \mathbf{5 5}$

Three specimens of charcoal combined, from excavation units C-D : 8-9, D.E: 8-9, and E-F: 8-9, in each case 30 in. to 36 in. below the excavation unit datum. These three excavation units were in alignment and occupied the same general position on the slope in front of the shelter; however, there was some question as to the validity of combining specimens from the three units. The deposits were presumed to be those of Zone 5. The artifacts were mainly of the Edwards Plateau Aspect; one Perdiz arrow point was found, but it may have fallen from a higher position. There was some evidence of previous disturbance in this area. Sample might be expected to date the latter part of the Edwards Plateau occupation. Comment: date seems recent, but not too much weight can be placed on it because of lumping of samples and evidence of previous disturbance. Note, however, that Tx-12 (this date list) is from a specimen stratigraphically deeper than one of the specimens combined to make the present sample, and is appropriately older.

\section{Tx-6. Kincaid No. 53}

$1120 \pm 60$

Charcoal from Test Pit 2, 30 in. to $36 \mathrm{in}$. below pit datum. The sample is from an ash lens in the upper part of Zone 5. No artifacts were in this level, but a Scallorn arrow point (Central Texas Aspect) was higher, and Edgewood and Pandora dart points (Edwards Plateau Aspect) were deeper. The hearth seems to have been built during the period of transition from Edwards Plateau Aspect to Central Texas Aspect. Comment: date seems reasonable in the light of what is now known.

Tx-12. Kincaid No. 12

$1765 \pm 145$

Charcoal from excavation unit E-F:8-9, 66 in. to 72 in. below excavation unit datum. This was in Zone 5 and all artifacts were of the Edwards Plateau Aspect, but there was no consistent point type sequence: points of Montell and Nolan type came from above this level, and Pedernales and Castroville points came from below; these relationships are at variance with sequences being determined at other sites. Two Clear Fork gouges came from this level. The specimen can be expected only to date some undefined point of time in the Edwards Plateau Aspect. Comment: date suggests late Edwards Plateau, thereby adding to the likelihood of mixture here.

Tx-13. Kincaid No. 50

$6695 \pm 360$

Charcoal and snail shells from Test Pit 3-B, 12 in. to 18 in. below pit datum. This pit was at the top of a talus slope, and it was difficult to equate its deposits with those of the alluvial terrace. The sample is from a gray-buff midden layer, probably in Zone 5, containing pockets and lenses of ash with bits of charcoal, as well as scattered hearthstones. One Pandora point and two Clear Fork gouges occurred in the same level as the sample. Pedernales points occurred above this level, Martindale and Kinney points below. This sample might be expected to date the middle part of the Edwards Plateau Aspect. Comment: date appears reasonable. 
Tx-17. Kincaid No. 72

$10,025 \pm 185$

Snail shells from excavation unit E-F :8-9, 84 in. to 90 in. below excavation unit datum, in Zone 5. There were no artifacts in this level, but in the level just below was the base of a projectile point or knife resembling the type Refugio, and a scraper-graver. The associated fauna is modern. The sample should date the early to middle part of the Edwards Plateau Aspect. Comment: date is older than anticipated. It contrasts with Tx-12 (1765 \pm 145 , this date list) which came from ca. $1 \mathrm{ft}$ higher in the same column. Some $8000 \mathrm{yr}$ seems an unduly long period for the deposit interval, especially since no unconformity was observed. However, Tx-12 may have been in a mixed deposit.

Tx-18. Kincaid No. 77

$9110 \pm 155$

Snail shells from excavation unit D-E:8-9, 84 in. to 90 in. below excavation unit datum, in Zone 5. There were no diagnostic artifacts in this level; only a bifacial chopper, an ovate knife, and two concave scrapers. The associated fauna is modern. The sample should fall fairly early in the Edwards Plateau Aspect. Comment: the date is earlier than expected, but is in proper sequence with $\mathrm{Tx}-19$ and $\mathrm{Tx}-20$ (this date list), which are from the same column.

Tx-19. Kincaid No. 78

$10,065 \pm 185$

Snail shells from excavation unit D-E:8-9, 90 in. to 96 in. below excavation unit datum, in Zone 5. This level yielded a bifacial hand axe, a scrapergraver, and a crude side scraper; there were no diagnostic artifacts. The associated fauna is modern. The sample should date fairly early in the Edwards Plateau Aspect. Comment: date is earlier than anticipated, but is in proper sequence with $\mathrm{T}_{\mathrm{x}}-18$ and $\mathrm{T}_{\mathrm{x}}-20$ (this date list), which are from the same column.

Tx-20. Kincaid No. 79

$10,365 \pm 110$

Snail shells from excavation unit D-E:8-9, 96 in. to 102 in. below excavation unit datum, in Zone 5 . This level yielded only a core and a very crude side scraper. The associated fauna is modern. The sample should date early in the Edwards Plateau Aspect. Comment: date is earlier than anticipated, but is in proper sequence with $\mathrm{Tx}_{\mathrm{x}} 18$ and $\mathrm{T}_{\mathrm{x}}-19$ (this date list) which are from the same column.

General comment: all dates from the same excavation units are in proper sequence. Dates on charcoal are for the most part reasonable, whereas dates on snail shells are older than expected.

\section{Punkinseed Shelter series, Texas}

Charcoal samples from Punkinseed Shelter (41 TV 48) on Lick Creek, a tributary of the Pedernales River, ca. $27 \mathrm{mi} \mathrm{W}$ of Austin in western Travis County, Texas $\left(30^{\circ} 22^{\prime} \mathrm{N}\right.$ Lat, $98^{\circ} 05^{\prime} \mathrm{W}$ Long). Deposits in the shelter consisted of ca. $1.5 \mathrm{ft}$ of unstratified limestone dust, limestone fragments, and scattered ashes, resting on a caliche floor. There was a great deal of disturbance by rodent burrowing, but samples for dating came from areas that did not 
show disturbance. Artifacts have not yet been completely studied, so that specific focus identification is tentative. Samples are from the first two $0.5 \mathrm{ft}$ levels below the surface. In both levels the diagnostic artifacts are Scallorn arrow points, indicating occupation by Austin Focus, Central Texas Aspect. Coll. and subm. 1961 by J. D. Scurlock, Univ. of Texas, Austin.

Tx-7. Punkinseed, 0.5-1.0 ft

$2355 \pm 185$

Charcoal from Square 100, 0.5 to $1.0 \mathrm{ft}$ below surface. Comment: in terms of current thinking, the date seems early for Austin Focus.

Tx-8. Punkinseed, 0-0.5 ft

$1140 \pm 90$

Two charcoal specimens combined, from adjoining Squares 100 and 101, 0 to $0.5 \mathrm{ft}$ below surface. Comment: date is in accord with information now accumulating concerning Austin Focus.

Tx-10. Blum Rockshelter, Texas

$1410 \pm 120$

Charcoal from Blum Rockshelter (41 HI 8) on Nolands River, a tributary of the Brazos River, $1 / 2$ mi NW of Blum, Hill County, Texas $\left(32^{\circ} 09^{\prime} \mathrm{N}\right.$ Lat, $97^{\circ} 24^{\prime}$ W Long), in Lake Whitney reservoir area. Excavation of this shelter has been reported by Jelks (1953). Sample is from Square J-7, 75 in. below the surface, just above the bottom of the deepest occupation zone, associated with Scallorn arrow points and other artifacts characteristic of Austin Focus, Central Texas Aspect. Sample should date the approximate beginning of Austin Focus occupation in this site, and possibly in northern Central Texas. Coll. and subm. 1952 by E. B. Jelks, River Basin Surveys, Austin, Texas. Comment: date fits well with current estimates for the appearance of the Austin Focus in Central Texas.

\section{Wunderlich site series, Texas}

Charcoal and shell samples from Wunderlich site (41 CM 3) an open occupation site on a low terrace of Rebecca Creek, a tributary of the Guadalupe River, ca. $20 \mathrm{mi}$ NW of New Braunfels, Comal County, Texas (29 55' N Lat, $98^{\circ} 2 \mathrm{l}^{\prime}$ W Long). Site consisted of two burned rock middens, Areas A and B. In Area A three periods are represented, in terms of projectile point sequence: Period I-primarily Nolan points; Period II-primarily Pedernales points; Period III-primarily Frio, Ensor, and related points. In Area B only Period II is represented. Following the terminology frequently used in this area, these periods represent respectively the Clear Fork, Round Rock, and Uvalde foci of the Edwards Plateau Aspect; but these foci are not universally accepted and are undergoing reexamination (Suhm, Krieger and Jelks, 1954, p. 102-104; Suhm, 1960, p. 79-81, 84) so that it is best for the present to speak only in terms of projectile point sequence. Coll. 1960 by C. D. Tunnell; subm. 1961 by E. B. Jelks and LeRoy Johnson, Jr., Texas Archeological Salvage Proj., Univ. of Texas, Austin.

\section{Tx-14. Wunderlich Area A, No. 1}

$4505 \pm 300$

Charcoal from Area A, Square N155-W40, elevation 193.0 to $193.5 \mathrm{ft}$, Stratum B. Nolan dart points are characteristic of this stratum, which is therefore assigned to Period I. Comment: date does not seem inappropriate in the 
present preliminary state of knowledge, but note inconsistency with $\mathrm{T}_{\mathrm{x}}-16$ (5405 \pm 300 , this date list) from same stratum.

\section{Tx-15. Wunderlich Area B}

$4170 \pm 200$

Mussell shells and snail shells from Area B, Square N207-W195, elevation 198.5 to $199.0 \mathrm{ft}$. Pedernale dart points are characteristic of Area B, which is therefore assigned to Period II. Comment: archaeologic evidence is that Pedernales dart points are more recent than Nolan points, hence a later date for this sample than for Tx-14 and Tx-16 (4505 \pm 300 and $5405 \pm 300$, this date list) which are associated with Nolan points, seems entirely appropriate.

Tx-16. Wunderlich Area A, No. 2

$\mathbf{5 4 0 5} \pm \mathbf{3 0 0}$

Charcoal from Area A, Square N162-W40, elevation 193.0 to $193.5 \mathrm{ft}$, Stratum B. Nolan points are characteristic of this stratum, which is therefore assigned to Period I. Comment: date is not inappropriate in the present state of knowledge, but is $900 \mathrm{yr}$ older than Tx-14 (4505 \pm 300 , this date list) from the same stratum. Both dates are appropriately older than $\mathrm{Tx}_{\mathrm{x}}-15$ (4170 \pm 200 , this date list) which is from Period II.

Date lists:

References

\section{Chicago III Libby, 1952 \\ Michigan I Crane, 1956 \\ Michigan III Crane and Griffin, 1958 \\ Michigan IV Crane and Griffin, 1959 \\ Michigan V Crane and Griffin, 1960 \\ USGS V Rubin and Alexander, 1960}

Anonymous, 1961, Benzene synthesis aids $\mathrm{C}^{14}$ dating: Chem. Eng. News, v. 39, no. 41 , p. 48.

Bell, Robert E., 1958, Radiocarbon dates from Oklahoma: Oklahoma Anthropol. Soc. Newsletter, v. 7, no. 3, p. 3-4.

Campbell, T. N., 1961, A list of radiocarbon dates from archeological sites in Texas: Texas Archeol. Soc. Bull., v. 30, p. 311-320.

Crane, H. R., 1956, University of Michigan radiocarbon dates I: Science, v. 124, p. 664 672 .

Crane, H. R., and Griffin, J. B., 1958, University of Michigan radiocarbon dates III: Science, v. 128, p. 1117-1123.

1959, University of Michigan radiocarbon dates IV: Am. Jour. Sci. Radioc. Supp., v. 1, p. 173-198.

1960, University of Michigan radiocarbon dates V: Am. Jour. Sci. Radioc. Supp., v. 2, p. 31-48.

Jelks, Edward B., 1953, Excavations at the Blum Rockshelter: Texas Archeol. Soc. Bull., v. 24, p. $189-207$.

Libby, W. F., 1952, Chicago radiocarbon dates III: Science, v. 116, p. 673-681.

Noakes, J. E., Isbell, A. S., and Hood, Donald W., 1961, Conversion of carbon dioxide to benzene for liquid scintillation counting: Am. Geophys. Union Trans., v. 42, no. 2, p. 226.

Rubin, Meyer, and Alexander, Corrinne, 1960, U. S. Geological Survey radiocarbon dates V: Am. Jour. Sci. Radioc. Supp., v. 2, p. 129-185.

Shapiro, I., and Weiss, H. G., 1957, Cyclization of acetylene $\mathrm{d}_{2}$ to benzene $\mathrm{d}_{6}$ : Amer. Chem. Soc. Jour., v. 79 p. 3294.

Suhm, D. A., 1960, A review of Central Texas archeology: Texas Archeol. Soc. Bull., v. 29, p. $63-107$.

Suhm, D. A., Krieger, A. D., and Jelks, E. B., 1954, An introductory handbook of Texas archeology: Texas Archeol. Soc. Bull., v. 25.

Tamers, M. A., Stipp, J. J., and Collier, J., 1961, High sensitivity detection of naturally occurring radiocarbon-I: chemistry of the counting sample: Geochim. et Cosmochim. Acta. v. 24 , p. $266-276$

Weiss, H. G., and Shapiro, I., 1958, Increased activity of silica-alumina catalysts: Am. Chem. Soc. Jour., v. 80, p. 3195-3198. 